\title{
Histopatological effects of bleaching and disease on the coral Siderastrea stellata from coastal reefs of Brazil
}

\author{
Cristiane F. Costa Sassi ${ }^{1,2}$ (i), Gabriel M. de Farias ${ }^{1}$ (i), Amanda de S. Vasconcelos ${ }^{1}$ (i), \\ Rebeca S. de Macedo' (1), Jéssica P. de S. França² (1) \& Roberto Sassi' (1)
}

\begin{abstract}
1. Universidade Federal da Paraíba Centro de Ciências Exatas e da Natureza, Departamento de Sistemática e Ecologia, Laboratório de Ambientes Recifais e Biotecnologia com Microalgas (UFPB/DSE/LARBIM). Cidade Universitária, 58059-900 João Pessoa, PB, Brazil

(cfcosta_ccosta@yahoo.com; gab-malta@hotmail.com; mandvasc@gmail.com; rebecamaceddo.bio@gmail.com; sassi_rs@yahoo.com.br)

2. Universidade Federal da Paraíba, Centro de Ciências Aplicadas e Educação, Programa de Pós-Graduação em Ecologia e Monitoramento Ambiental (UFPB/CCAE/PPGEMA). Av. Santa Elisabete, s/n, Centro, 58297-000 Rio Tinto, PB, Brazil. (jmps.franca@gmail.com)
\end{abstract}

Received 26 August 2020

Accepted 23 March 2021

Published 07 May 2021

DOI 10.1590/1678-4766e2021007

\begin{abstract}
Histological analysis of bleached samples of Siderastrea stellata Verrill, 1868, with white plague disease and with alteration in the color pattern, revealed drastic tissue and cellular disturbances, such as lysis of the external epithelium, hyperplasia of gastrodermis, apoptosis of epithelial cells and zooxanthellae, and degradation of mesenteric filaments and reproductive cells. Fungal hyphae, diatoms, and cyanobacteria were present in diseased samples and colonies with alteration in the color pattern. Furthermore, bleached and diseased samples showed significant reductions in the number of zooxanthellae per $100 \mu \mathrm{m}^{2}$ of gastrodermis and significant reductions in the diameters and volumes of stage $\mathrm{V}$ oocytes. We found that bleaching events, diseases, and colonies with alteration in the color pattern promoted degradation of reproductive cells, resulting in the consequent interruption of the reproduction of the coral S. stellata, which is one of the most common Brazilian coral species. The implications of these indirect effects of bleaching, disease, and changes in coral color patterns in the population dynamics of Brazilian reefs are discussed.
\end{abstract}

KEYWORDS. Brazilian reefs, coral diseases, coral bleaching, histopathology, cellular disturbances.

RESUMO. Efeitos histopatológicos dos eventos de branqueamento e doenças no coral Siderastrea stellata dos recifes costeiros do Brasil. Análises histológicas de amostras de Siderastrea stellata Verrill, 1868 branqueadas, doentes e com alteração no padrão de cloração, revelaram drásticas perturbações teciduais e celulares, como lise do epitélio externo, hiperplasia da mesogleia, apoptose das células epiteliais e das zooxantelas, e degradação dos filamentos mesentéricos e das células reprodutivas. Hifas fúngicas, diatomáceas e cianobactérias estavam presentes em amostras doentes e em tecidos de colônias com alteração no padrão de coloração. Além disso, amostras branqueadas e doentes apresentavam reduções significativas no número de zooxantelas por $100 \mu \mathrm{m}^{2}$ da gastrodermis e, reduções significativas nos diâmetros e volumes dos oócitos de estágio V. Constatamos que eventos de branqueamento, doenças e colônias com alteração no padrão de cloração, promoveram degradação das células reprodutivas, resultando na consequente interrupção da reprodução do coral S. stellata, que é uma das espécies de corais brasileiro mais comuns. As implicações desses efeitos indiretos do branqueamento, doenças e das mudanças nos padrões de coloração dos corais na dinâmica populacional dos recifes brasileiros são discutidas.

PALAVRAS-CHAVE. Doenças em corais, branqueamento de coral, histopatologia, recifes brasileiros, perturbações celulares.

Studies concerning the incidence and prevalence of diseases in corals are one of many threats to coral reefs all around world, and the numbers of species affected have increased considerably in recent years (TRAYLOR-KNOWLES $e t$ al., 2017; RodRíGUEZ-VILLALOBOS \& ReYES-BonilLa, 2019). Disease events have been associated with significant declines in the populations of reef-building species and changes in the community dynamics of corals affecting the trophic economy and coral reefs productivity (TRAYLOR-KNOWLES et al., 2017; Wall et al., 2018; RodRÍGUEZ-VILLALOBOS \& REYes-Bonilla, 2019).

The history of investigations into coral diseases dates to approximately 1970 , with the first reports of black band disease (BBD) in the Caribbean and Indo-Pacific regions (ANTONIUS, 1988; RichaRdSON, 1998). More than thirty- five different types of diseases affecting corals have now been reported from approximately 70 countries (PORTER et al., 2011; PALMER et al., 2011; RodríGUEZ-VILLALOBos \& Reyes-Bonilla, 2019), but despite the progressive increase in publications on the subject, most diseases and their etiological agents remain unclear. Also, most of the work on coral diseases involved only field research with little histopathology, thus making it difficult to understand the causes of coral diseases.

According to the literature, although most pathogens involved in the manifestations of coral diseases naturally inhabit coral communities, it is believed that their interactions with various elements of environmental stress exacerbate their negative effects (BAN et al., 2014; MonTILla et al., 2019). As the microorganism communities observed in healthy tissues 
are largely the same as those present in diseased tissues, additional techniques will be needed to better understand the appearance of serious diseases among corals (MoREIRA et al., 2014). For this reason, researchers from many countries have used histological techniques that allow spatial visualization of microorganisms associated with healthy and diseased tissues, assisting in the assessment of damage to coral tissue and manifestations of diseases (WORK et al., 2016; TrAYLORKNOWLES et al., 2017).

Although several approaches and sophisticated tools have been employed in different parts of the world to examine bleaching and disease events in corals, most studies undertaken in Brazil have been limited to macroscopic descriptions, such as bleaching and disease percentages (Francini-Filho et al., 2008; Costa SASSI et al., 2014; SOARES \& RABELO, 2014; SASSI et al., 2015), the geographic distributions and seasonality of these events (ACOSTA, 2001; Francini-Filho et al., 2008; Costa et al., 2013; Costa SASSI et al., 2014), studies directed toward the composition of microorganisms that could be cultivated (MoREIRA et al., 2014), and quantification of microorganisms associated with healthy and bleached tissues (COSTA SASSI et al., 2014; SASSI et al., 2015).
These approaches, however, have not been sufficient for accurate diagnosis of coral diseases, and they do not increase our understanding of their real consequences to these organisms. Therefore, we aim to describe the tissue and cellular damage that the bleaching events, diseases, and pigmented tissue promote on coral Siderastrea stellata Verrill, 1868 , which is one of the most common coral species that occur along the Northeast and Southeast coasts of Brazil. In addition, this species, along the Brazilian coast, has been suffering from frequent bleaching and disease events, although with a very low mortality rate (COSTA SASSI et al., 2014; SASSI et al., 2015; TEIXEIRA et al., 2019).

\section{MATERIAL AND METHODS}

Study site and sample collections. This research was carried out on the reefs of Ponta do Seixas (State of Paraíba, Brazil) located $700 \mathrm{~m}$ from the continent (Fig. 1). Ponta do Seixas Reef are part of the most visited group of coastal reefs in the state of Paraíba, are inserted in the state marine preservation area (APA Naufrágio Queimado), and several bleaching events have been reported in this area affecting several coral species, including Siderastrea stellata (COSTA SASSI et al., 2014; SASSI et al., 2015).
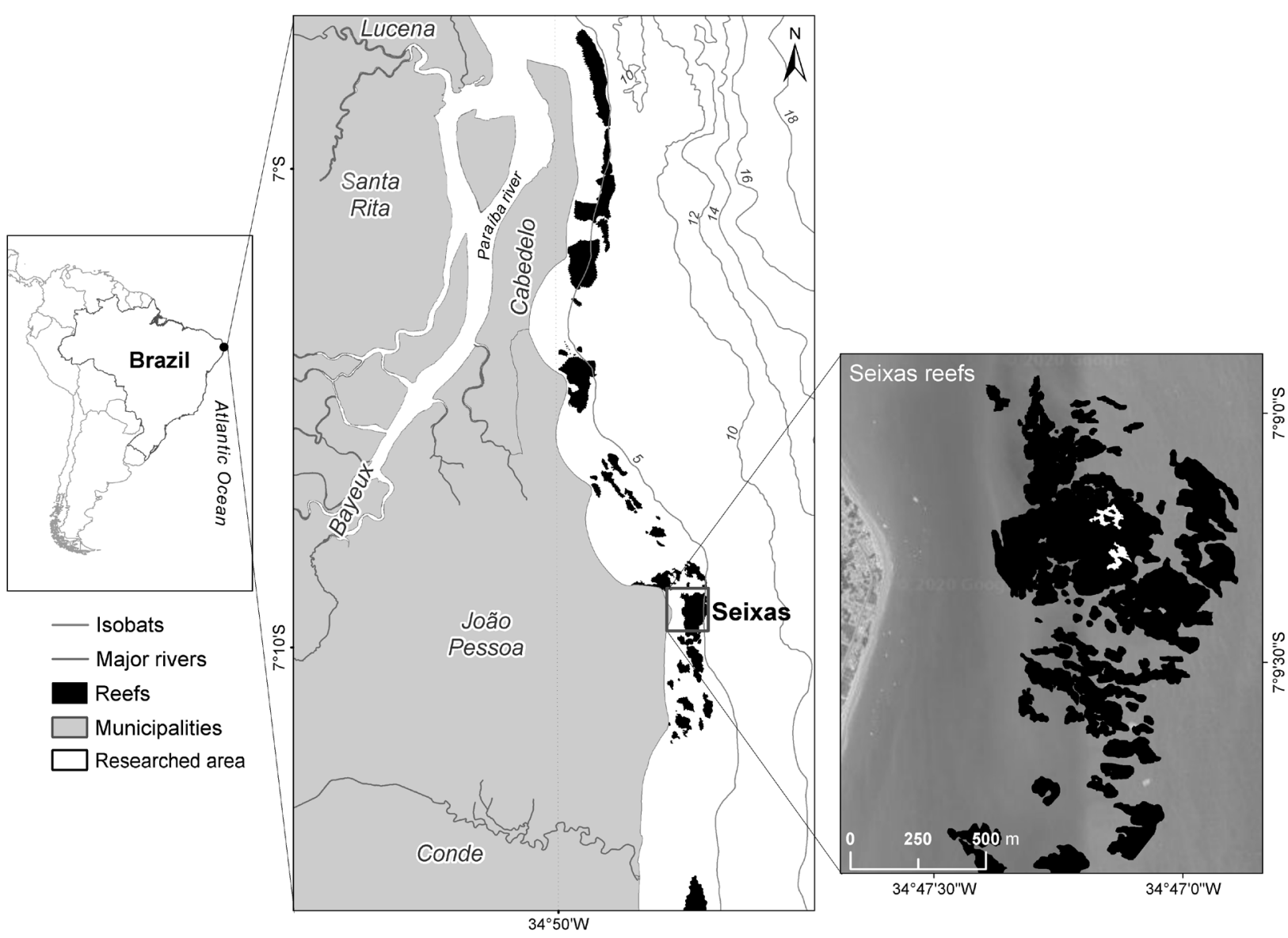

Fig. 1. Areas where corals were sampled, Ponta do Seixas, state of Paraíba, Brazil. 
During each month between September 2018 and July 2019, four fragments of $5 \mathrm{~cm}$ in diameter of the coral Siderastrea stellata in healthy conditions, bleached, with white plague disease, and with alteration in the color pattern were collected using a hammer and chisel (a total of 176 fragments were collected). In the case of white plague disease specimens, a paired sample (a sample of healthy tissue and a sample of tissue from lesions in each affected colony) was taken. The samples were individually kept in plastic bags, fixed in a saline $10 \%$ formalin, and transported to the Laboratório de Ambientes Recifais e Biotecnologia com Microalgas - LARBIM of the Universidade Federal da Paraíba, where they were processed. All corals were sampled from within a $2 \mathrm{~m}$ depth.

The healthy specimens (Fig. 2a) showed a goldenbrown color characteristic of the $S$. stellata and were classified with scores of 5 or 6 following the criteria of the Coral Health Chart. The bleached specimens (Fig. 2b) were classified with scores of 1 or 2 following the criteria of the Coral Health Chart (severely bleached according to SIEBECK et al., 2006). The specimens with white plague disease had an irregularly shaped white lesion, with focal distribution and located on the periphery of the colony (Fig. 2c).

The specimens with diffuse pink discoloration (Fig. 2d) were considered to have a color pattern that was not characteristic of healthy colonies of Siderastrea stellata. According to Costa SASSI et al. (2014) and SASSI et al. (2015) pink pigmentation represents an early stage of bleaching documented in Brazilian coastal reefs and needs to be examined more deeply. Thus, all pink specimens collected in this study will be considered to have a pigmentation pattern altered (PPA) following SASSI et al. (2015).

Histological analysis. After 12 hours of fixation, the coral samples were decalcified in a $10 \%$ formic acid and $5 \%$ formalin solution, after placed in running tap water to remove acid traces following PIRES et al. (2014). After decalcification, the samples were dehydrated in an ethanol series $(70 \%, 80 \%$, $90 \%$ and $100 \%$ ), cleared in xylene, embedded in paraffin, sectioned longitudinally and transversely $(5-7 \mu \mathrm{m})$, and stained with Hematoxylin and Eosin (H\&E). Grocott's stain was used to verify the presence of bacteria and fungi. Ten slides were prepared from each fragment collected for each type of stain.

All histological slides were analyzed, using a Leica trinocular microscope DM 2500 to evaluate the integrity and organization of the tissue layers, their cellular constituents, the presence of associated microorganisms, zooxanthellae integrity, presence and aspects of reproductive structures, and measures of the thickness of the external epithelium.

In cases where stage $\mathrm{V}$ oocytes (those showing nucleus and nucleolus) were observed, measurements of their dimensions (size and volume) were performed from cross sections following GLYNN et al. (1994) and SHIKINA et al. (2012). The measurements of oocyte diameter $(\mathrm{n}=140$ randomly chosen oocytes per sample for each coral health condition), and measures of the thickness of the external epithelium ( $\mathrm{n}=50$ measurements randomly chosen per sample for each coral health condition) were made in cross sections using a previously calibrated micrometric eyepiece.

Three histological slides for each condition (healthy, bleached, with white plague disease, and PPA colonies) were photographed at $400 \mathrm{x}$ to determine the number of symbiotic algae (zooxanthellae) within $100 \mu \mathrm{m}^{2}$ of gastrodermis, following PALMER et al. (2008). Photographs were taken of the epidermal layers in the free body wall region in longitudinal sections of polyps of Siderastrea stellata, using a Leica DFC295 camera attached to the Leica trinocular microscope DM 2500 coupled to a PC microcomputer. The number of zooxanthellae within $100 \mu \mathrm{m}^{2}$ of the gastrodermis was recorded in 15 randomly selected areas of healthy, bleached, diseased, and pigmented tissue longitudinal sections. The IMAGE J software was used to calculate the tissue area.

Statistical analysis. The degrees of homoscedasticity, as well as the normality of all the histological variances, were tested using the Levene and Shapiro tests respectively. The means of the variables of the tissues (external epithelium thickness, population density of zooxanthellae per $100 \mu \mathrm{m}^{2}$ of gastrodermis, and the diameters and volumes of the stage $\mathrm{V}$ oocytes) were analyzed in healthy and bleached colonies as well as in those showing white plague disease, and PPA colonies and compared by variance analysis (ANOVA-Oneway) and Tukey's HSD test. When the variances did not demonstrate normality, non-parametric tests were used. All the statistical treatments were made using Statistica 10.0 software, at a $5 \%$ level of significance, following the recommendations of ZAR (2010).

\section{RESULTS}

Bleaching events and diseases promoted drastic alterations in the cellular and tissue architectures of the coral S. stellata. Healthy samples showed normal tissue with columnar epithelium, thin mesoglea and gastrodermis replete with zooxanthellae, healthy epithelial layers of the body wall (Fig. 2a.1). Bleached samples, on the other hand, exhibited fragmentation and/or reductions in the thickness of the external epithelium, hyperplasia of the mesoglea due to increased mucocytes cell sizes, and necrosis of gastrodermis (2b.1). White plague disease samples demonstrated hypertrophy of their caliciform cells, rupture of the external epithelium due to the presence of many mucocytes, apoptosis of epithelial cells, and focal vacuolation of gastrodermis (Fig. 2c.1). The PPA colonies tissues exhibited apoptosis of the epithelial cells and zooxanthellae, with an appearance of the cells that often made their boundaries indistinct due to the absence of observable cellular contours; under those conditions, their tissues were totally fragmented, and necrosis of eternal epithelium is evident (Fig. 2d.1). Apoptosis of the epithelial cells and zooxanthellae were observed in $80.95 \%$ of the slides of bleached tissue, and in $100 \%$ of the slides of tissues from colonies suffering from white plague disease or that were pigmented; healthy tissues were not observed. 


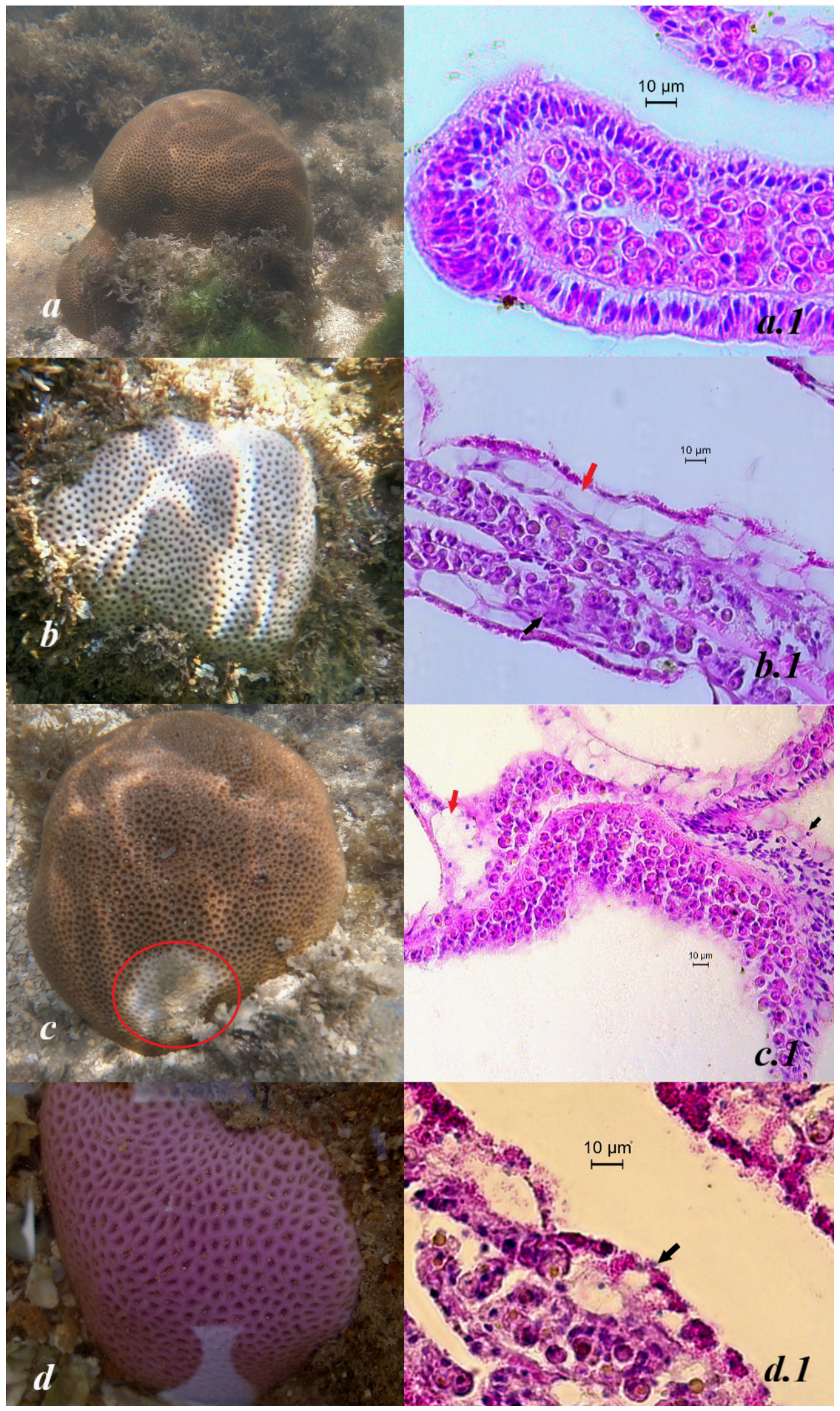

Fig. 2. Siderastrea stellata Verrill, 1868 colonies healthy conditions (a), bleached (b), white plague disease (c), and colonies with pigmentation pattern altered (PPA) (d). And their respective histological sections, stained in H \& E: $a .1$, healthy body wall epithelial layers; $b .1$, body wall with gastrodermis and mucus laden calicodermis, black arrow pointing to necrosis of gastrodermis, and red arrow pointing to mucocytes promote hyperplasia of the mesoglea; c. 1, epithelium disrupted and presence of many mucocytes (black arrow), and focal vacuolation of gastrodermis (red arrow); $d .1$, basal body wall with calicodermis, and necrosis of eternal epithelium (black arrow). 
The analyses of those slides allowed us to classify the appearance of the external epithelium into three categories: (i) intact (when the epithelial and caliciform cells were intact and three coral tissue layers could be observed, as well as the basal laminar and cell outlines; Fig. 2al), (ii) fragmented (when the shapes and contours of the epithelial cells could not be distinguished and have increased mucocyte cell sizes; Fig. $2 b 1$ ) and, (iii) epithelium not seen (when the epithelium could not be distinguished, with apoptosis of the epithelial cells and zooxanthellae, or if those structures were dispersed throughout the slide; Fig. $2 c 1$ ).

In those analyses, $68.42 \%$ of the slides of healthy tissues demonstrated an intact epithelium, while $31.58 \%$ of the slides showed a fragmented epithelium. The slides of bleached tissues showed $71.43 \%$ having fragmented epithelium, $12.13 \%$ having absence of epithelial structure, and $16.44 \%$ demonstrated intact epithelium. All slides (100\%) of the white plague disease and PPA colonies samples had fragmented epithelium.

It was also observed that bleaching events, white plague disease, and PPA colonies tissues, resulted in significant reductions in the thickness of the external epithelium. The mean thickness of the external epithelium was significantly greater in healthy samples $(10.64 \pm 0.79$ $\mu \mathrm{m}$ ) than in bleached (of $7.04 \pm 0.59 \mu \mathrm{m}$ ), white plague disease $(5.40 \pm 0.57 \mu \mathrm{m})$ or PPA colonies tissue $(5.09 \pm 0.34$ $\mu \mathrm{m})($ mean $\pm \mathrm{SD})(F=122.8381 ; d f=3 ; p<0.05)$.

Several microorganisms were observed on the slides of healthy, bleached, and diseased colonies and PPA colonies. Zooxanthellae and diatoms were observed in healthy tissues, while bleached tissues and those showing white plague disease contained, in addition to symbiotic zooxanthellae, various other microorganisms such as diatoms, cyanobacteria, and fungi (Fig. 3). Grocott's staining revealed that all of the slides of bleached tissue, white plague disease, and PPA colonies tissues showed the distinct presence of fungal hyphae, including within the mesenteric filaments responsible for the nutrition of coral reproductive structures (Fig. 3c,d).

Comparisons of histological sections revealed that the mean numbers of zooxanthellae per $100 \mu \mathrm{m}^{2}$ of gastrodermis were significantly greater in healthy samples $(0.67 \pm 0.22$ cells $100 \mu \mathrm{m}^{2}$ of gastrodermis) than in white plague disease samples $\left(0.01 \pm 0.02\right.$ cells. $100 \mu \mathrm{m}^{2}$ of gastrodermis $)$ or PPA colonies tissue samples $\left(0.22 \pm 0.09\right.$ cells. $100 \mu \mathrm{m}^{2}$ of gastrodermis) (mean $\pm \mathrm{SE})(K W-H(3 ; 79)=64,19 ; p<$ 0.05; Fig. 4).

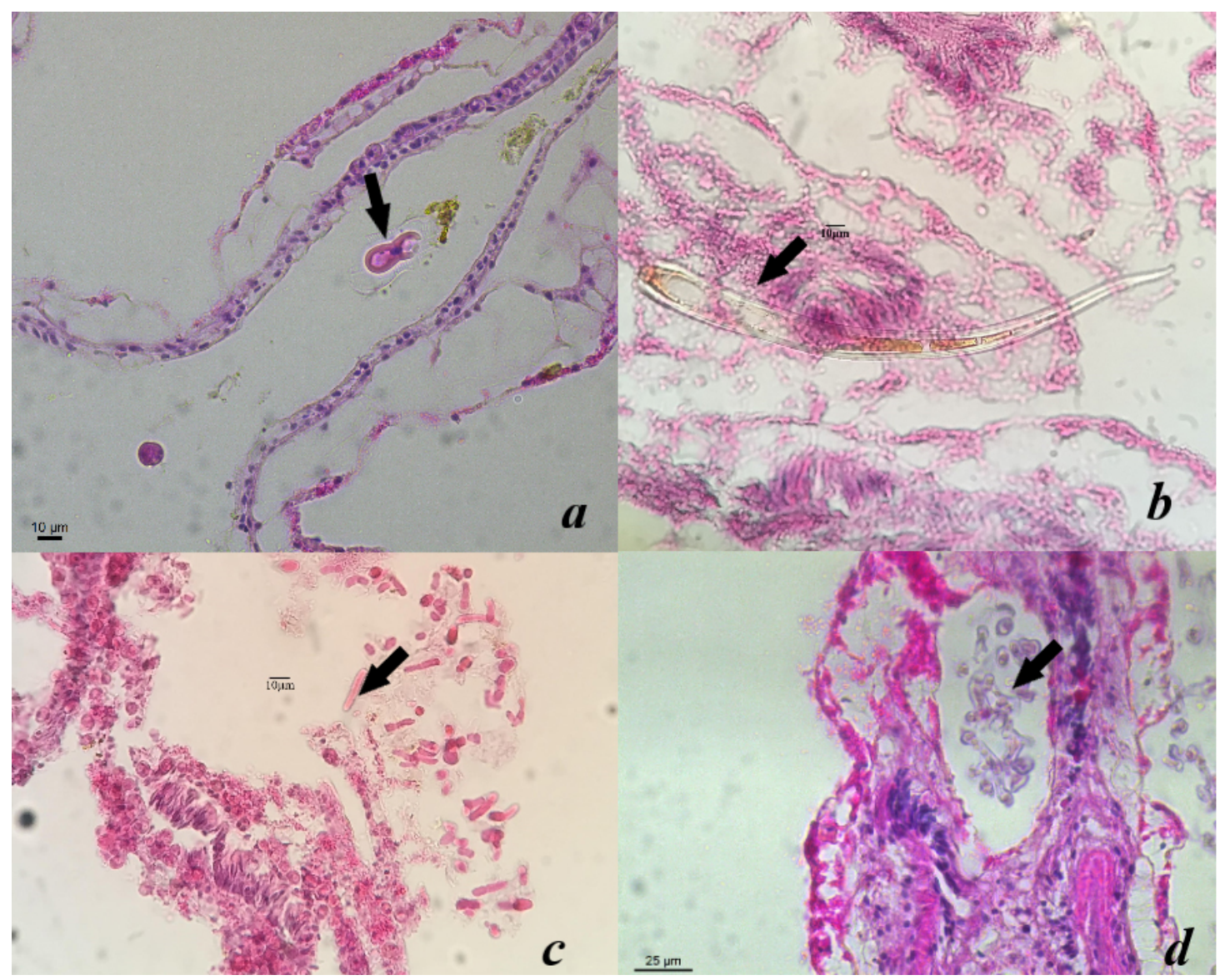

Fig. 3. Photomicrographs of organisms associated with bleached sample (a) black arrow is pointing to diatom (see striated frustule) on the surface of corals. The epidermis is atrophied and cuboidal and gastrodermis is bereft of zooxanthellae (atrophy) and markedly vacuolated; b, dead autolyzed tissue with another likely diatom (black arrow); c-d, dissociated tissues with fungal hyphae (black arrow); d, shows fungal hyphae (black arrow) invading coral tissue with necrosis. 


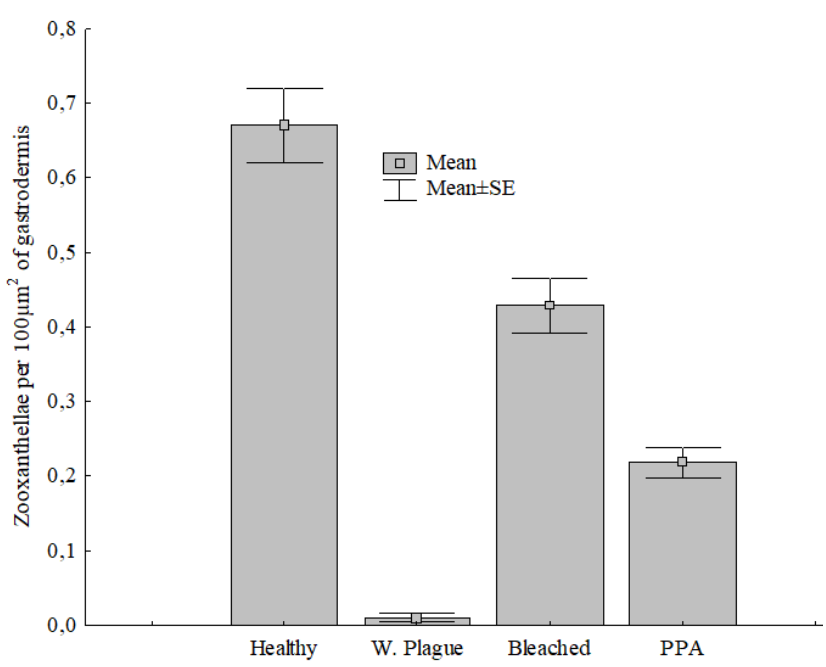

Fig. 4. Comparison of mean densities of zooxanthellae per $100 \mu \mathrm{m}^{2}$ of gastrodermis between healthy samples, bleached, white plague diseased and colonies of coral Siderastrea stellata Verrill, 1868 with pigmentation pattern altered (PPA).
Female reproductive structures (oocytes) were observed in all samples examined (healthy, bleached, diseased, and or PPA colonies). On the other hand, male reproductive structures (spermatids) were present only in white plague disease samples and planula larva were found in healthy and PPA colonies samples. We observed degradation of stage $\mathrm{V}$ oocytes and spermatids in bleached, PPA colonies, and diseased samples. However, in healthy samples, stage $\mathrm{V}$ oocytes showed resorption aspects (Fig. 5a,b). In addition, we observed that bleached and white plague disease samples showed damage to the mesenteric filaments, visible losses of cell integrity, presence of many large pink granules in gastrodermis and calicodermis, zooxanthellae in various stages of degradation, apoptosis of their epithelial cells, and epithelial lysis (Fig. 5d).

The mean size of the stage $\mathrm{V}$ oocytes of bleached samples were significantly smaller than those of healthy and diseased samples $(K W-H(3,225)=12.58177 ; p<0.05$; Tab. I). The mean volumes of stage $\mathrm{V}$ oocytes were quite small among bleached sample than those of healthy and diseased samples, and significantly larger in PPA samples colonies $(K W-H(3,225)=11.71427 p<0.05$; Tab. I $)$.

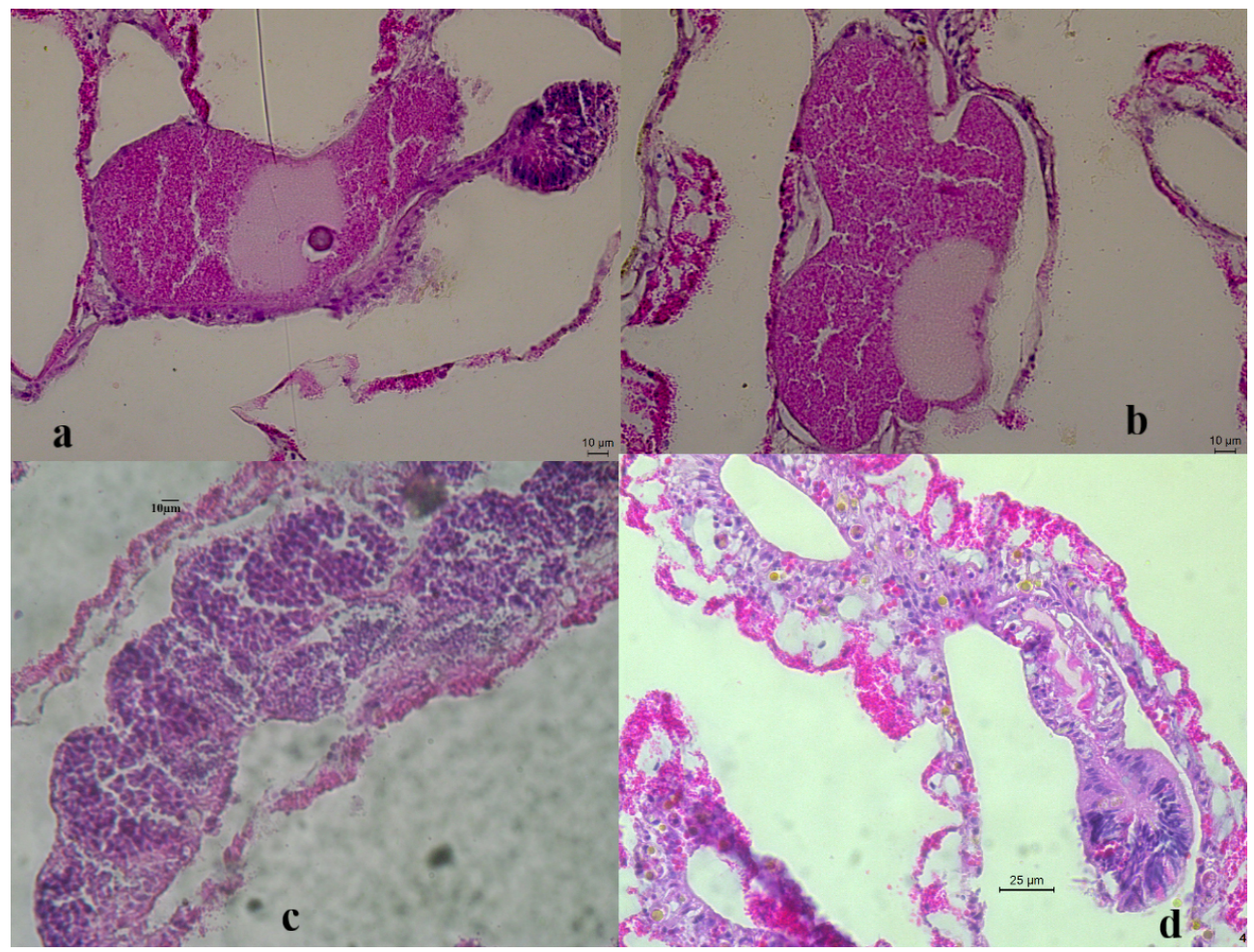

Fig. 5. Degraded reproductive structures of Siderastrea stellata Verrill, 1868: a-b, stage V oocytes from healthy sample; c, spermatids from white plague disease samples; d, mesenteric filaments from bleached sample. Note in (d) black arrow points tonecrosis of mesenteric filaments.

Tab. I. Size and volumes of stage V oocytes (Mean \pm SD) of Siderastrea stellata Verrill, 1868. Similar letters indicate no statistical difference.

\begin{tabular}{lcc}
\hline Health condition of colonies & Diameters of stage V oocytes $(\mu \mathrm{m})$ & Volumes of stage V oocytes $\left(\mathrm{mm}^{3} \times 10^{6}\right)$ \\
\hline Healthy & $355.01 \pm 209.13^{\mathrm{a}}$ & $160.89 \pm 236.17^{\mathrm{a}}$ \\
Bleached & $258.18 \pm 84.86^{\mathrm{b}}$ & $29,00 \pm 27,41^{\mathrm{b}}$ \\
White plague & $353.65 \pm 177.95^{\mathrm{a}}$ & $150.16 \pm 215.50^{\mathrm{a}}$ \\
Pigmented tissue & $445.36 \pm 164.09^{\mathrm{c}}$ & $187.98 \pm 142.24^{\mathrm{a}}$ \\
\hline
\end{tabular}




\section{DISCUSSION}

The histological techniques used in this research demonstrated the severity of the impacts that disease and coral bleaching events promote on the body layers of Siderastrea stellata, on the population density of its zooxanthellae and on the reproductive structures. In addition, diseased and tissues pigmented samples showed the marked presence of fungi, diatoms, and cyanobacteria. These data demonstrate that visual inspections in the field provide incomplete diagnoses of the real health conditions of the corals. WorK et al. (2016) reinforce that the lesions observed in the field have multiple etiologies and reflected distinct host responses (which varied from tissue fragmentation to cell apoptosis) demonstrating the important utility of histopathological analyses.

We found that pink pigmentation of S. stellata, considered an early stage of bleaching documented in Brazilian coastal reefs by SASSI et al. (2015), show all the serious histological changes observed in bleached and diseased coral samples. Thus, alterations in the color patterns of coral species represent signals of debilitated coral health (Williams et al., 2011; WORK \& AEBY, 2011; WorK \& METEYER, 2014). In the present study, the pink pigmentation of tissues of $S$. stellata was also associated with significant reductions in zooxanthellae density as well as drastic tissue and cellular alterations.

Work et al. (2016) reported that the agents most commonly associated with tissue loss in coral disease were algae and fungi, and the most common host responses were fragmentation and necrosis. These data are consistent with our findings, since we observed several microorganisms, such as diatoms, cyanobacteria, and fungi, in samples of bleached and disease tissues.

Of the 492 articles published between 1965 and 2013 analyzed by Work \& MeteYer (2014), 21\% described microscopic pathologies in corals and, of these, $57 \%$ involved histological analyzes. These researchers noted that publications that did not provide information concerning on cell and tissue pathology provided only very incomplete assessments, because for them, to better understand the coral disease, it is important to look at coral cells.

The reductions in the thickness of the external epithelium observed in bleached samples, diseased, and with diffuse pink discoloration must certainly influence the coral health, as epithelial layers are responsible for physically protecting the organism, absorbing required substances from the aquatic environment, and producing mucus (PALMER et al., 2008). Moreover, apoptosis of the epithelial cells also signals the weakening of the coral's immune system, as these cells work by protecting the organisms from solar radiation and produce melanin, which is considered a key ingredient for coral immunity (PALMER et al., 2008).

According to Work et al. (2016) and TraYlorKNOWLES et al. (2017), the increase in the numbers and sizes of mucocyte cells in bleached and diseased tissues of $S$. stellata represent a physiological response to risk situations in corals. In addition, the conservation status and myocyte cell shapes are clues to the damage suffered by corals when exposed to certain stressors (WORK \& AEBY, 2011; WORK et al., 2016).

All publications that described the histopathological effects caused by bleaching events and diseases in corals reported increases in myocyte cells, fragmentation and/ or tissue necrosis, cell apoptosis, and hypertrophy of the gastrodermis cells. These descriptions are consistent with our findings and indicate that tissue health was also compromised in the pigmented samples of this study.

We found significant reductions in the densities of zooxanthellae within the gastrodermis layer of bleached, diseased, and diffuse pink discoloration tissues of Siderastrea stellata, indicating that the health of the coral was quite compromised. Similar results have been reported by PALMER et al. (2008) and TraYlor-KNowles et al. (2017). Many research reports that when the immunological systems of coral species are activated, one of the first responses is the expulsion of their zooxanthellae (PALMER et al., 2008).

During our analyses, female reproductive structures were observed in all specimens of $S$. stellata. However, male reproductive structures were only observed in diseased samples. This observation may largely reflect the sample collection period, since $S$. stellata has oogenesis lasting for approximately 10 months, while spermatid production occurs only during specific months (BARRos et al., 2003; NeVes \& Silveira, 2003).

The presence of degraded oocytes in bleached and diseased samples shows the indirect effects of these events on corals which interrupt reproductive processes as a manner of avoiding excessive energetic outlays, although that aspect will also require additional investigations (BORGER \& COLLEY, 2010). On the other hand, healthy tissues demonstrate rare examples of stage I and $\mathrm{V}$ oocyte with vitelline membrane broken or absent, possibly indicating partial reproductive failure (Szmant-Froelich et al., 1980; Neves \& Pires, 2002), or according to ST. GELAIS et al. (2016), a chronologically staged biological process of Siderastrea.

According to BARROS et al. (2003), although stage V oocytes are mature enough to be released, coral reproductive strategies can be influenced by environmental conditions. This explains the presence of degraded or reabsorbed stage $\mathrm{V}$ oocytes observed in bleached and healthy samples collected from reefs subject to different anthropogenic stressors such as the Ponta do Seixas reefs (Costa et al., 2007).

In conclusion, this work provides new information on the effects of bleaching events and diseases on the coral Siderastrea stellata, which were manifested as cellular and tissue alterations, affected reproductive aspects of those cnidarians, and promoted a possible interruption in the reproductive cycle of this species, which is one of the main builders of Brazilian reefs. The data presented here clearly demonstrate the necessity to incorporate histological techniques to more fully understand the severity of the impacts of coral bleaching events, white plague diseases, and change in color patterns of S. stellata. The implications 
of these indirect bleaching effects, diseases and changes in coral color patterns need to be further investigated.

Acknowledgments. We thank the Fundação Grupo Boticário de Proteção à Natureza (grant no: 1115_20181) for their financial support. We also thank Fundação de Apoio à Pesquisa do Estado da Paraíba for granting the scholarship. The authors also thank to anonymous reviewers by their important contributions.

\section{REFERENCES}

Acosta, A. 2001. Disease in zoanthids: dynamics in space and time. Hydrobiologia 460:113-130.

Antonius, A. 1988. Distribution and dynamics of coral diseases in the Eastern Red Sea. Proceeding of 6th International Coral Reef Symposium 2:293-298.

Ban, S. S.; Graham, N. A. J. \& Connolly, S. R. 2014. Evidence for multiple stressor interactions and effects on coral reefs. Global Change Biology 20:681-697.

Barros, M. M. L. De; Pires, D. O. \& Castro, C. B. 2003. Sexual reproduction of the Brazilian reef coral Siderastrea stellata Verrill, 1868 (Anthozoa, Scleractinia). Bulletin of Marine Science 73(3):713-724.

Borger, J. L. \& Colley, S. 2010. The effects of a coral disease on the reproductive output of Montastraea faveolata (Scleractinia: Faviidae). Revista de Biologia Tropical 58(Suppl. 3):99-110

Costa, C. F.; Sassi, R.; Costa, M. A. \& Brito, A. C. L. 2007. Recifes costeiros da Paraíba, Brasil: usos, impactos e necessidades de manejo no contexto da sustentabilidade. Gaia Scientia 1(1):37-45.

Costa, C. F.; Sassi, R. \& Gorlach-Lira, K. 2013. Diversity and seasonal fluctuations of microsymbionts associated with some scleractinian corals of the Picãozinho reefs of Paraíba State, Brazil. Pan-American Journal of Aquatic Sciences 8(4):240-252.

Costa Sassi, C. F.; Sassi, R.; Gorlack-Lira, K. \& de Lima, C. P. 2014. Pigmentation patterns of Siderastrea stellata Verrill, 1868 (Cnidaria, Scleractinia) from coastal reefs in northeastern Brazil and its relation with zooxanthellae and other microsymbionts. Pan-American Journal of Aquatic Sciences 9(3):207-222.

Francini-Filho, R. B.; Thompson, F. L.; Reis, R. M.; Kaufman, L. E. S.; KIKUCHI, R. K. P. \& LeÃo, Z. M. A. N. 2008. Diseases leading to accelerated decline of reef corals in the largest South Atlantic reef complex (Abrolhos Bank, eastern Brazil). Marine Pollution Bulletin 56:1008-1014.

Glynn, P. W.; Colley, S. B.; Eakin, C. M.; Smith, D. B.; Cortes, J.; Gassman, N. J.; Guzmfin, H. M.; Rosario, J. B. Del \& Feingold, J. S. 1994. Reef coral reproduction in the eastern Pacific: Costa Rica, Panamfi, and Galfipagos Islands (Ecuador). II. Poritidae. Marine Biology 118:191-208.

Montilla, L. M.; Ascanio, A.; Verde, A. \& Croquer, A. 2019. Systematic review and meta-analysis of 50 years of coral disease research visualized through the scope of network theory. PeerJ 7:e7041 http://doi. org/10.7717/peerj. 7041

Moreira, A. P. B.; Tonon, L. A. C.; Pereira, C. V.; Alves, Jr. N.; AmadoFilho, G. M.; Francini-Filho, R. B.; Paranhos, R. \& Thompson, F. L. 2014. Culturable heterotrophic bacteria associated with healthy and bleached scleractinian Madracis decactis and the Fireworm Hermodice carunculata from the Remote St. Peter and St. Paul Archipelago, Brazil. Current Microbiology 68:38-46.

Neves, E. G. \& Pires, D. O. 2002. Sexual reproduction of Brazilian coral Mussismilia hispida (Verrill, 1902). Coral Reefs 21:161-168.

Neves, E. G. \& Silveira, F. L. 2003. Release of planula larvae, settlement and development of Siderastrea stellata Verrill, 1868 (Anthozoa, Scleractinia). Hydrobiologia 501:139-147.

Palmer, C. V.; Mydlarz, L. D. \& Willis, B. L. 2008. Evidence of an inflammatory-like response in non-normally pigmented tissues of two scleractinian corals. Proceedings of the Royal Society B: Biological Sciences 275:2687-2693.

Palmer, C. V.; Traylor-Knowles, N. G.; Willis, B. L. \& Bythell, J. C. 2011. Corals use similar immune cells and wound-healing processes as those of higher organisms. PloS One 6(8):e23992; 10.1371/journal. pone.0023992.

Pires, D. O.; Silva, J. C. \& Bastos, N. D. 2014. Reproduction of deep-sea reef-building corals from the southwestern Atlantic. Deep-Sea Research Part. II: Topical Studies in Oceanography 99:51-63.

Porter, J. W.; Torres, C.; Sutherland, K. P.; Meyers, M. K.; Callahan, M. K.; Ruzicka, R. \& Colella, M. 2011. Prevalence, severity, lethality, and recovery of dark spots syndrome among three Floridian reef-building corals. Journal of Experimental Marine Biology and Ecology 408:79-87

RichardSON, L. L. 1998. Coral diseases: what is really known? Trends in Ecology \& Evolution 13(11):438-443.

RodríGuez-Villalobos, J. C. \& Reyes-Bonilla, H. 2019. History of perspectives on the study of coral disease in the eastern tropical Pacific. Diseases Aquatic Organisms 136:243-253.

Sassi, R.; Costa Sassi, C. F.; Gorlach-Lira, K. \& Fitt, W. K. 2015. Pigmentation changes in Siderastrea spp. during bleaching events in the costal reefs of northeastern Brazil. Latin American Journal of Aquatic Research 43(1):76-185.

Shikina, S.; Chieh-Jhen, C.; Jhe-Yu, L.; Zi-Fan, S.; Yi-Jou, C.; YANHorn, L. \& Ching-Fong, C. 2012. Germ cell development in the scleractinian coral Euphyllia ancora (Cnidaria, Anthozoa). PloS One 7(7):e41569. doi:10.1371/journal.pone.0041569

Siebeck, U. E.; Marshall, N. J. \& Kluter, A. 2006. Monitoring coral bleaching using a colour reference card. Coral Reefs 25:453-460. doi: 10.1007/s00338-006-0123-8

Soares, M. O. \& Rabelo, E. F. 2014. Primeiro registro de branqueamento de corais no litoral do Ceará (NE, Brasil): indicador das mudanças climáticas? Geociência 33(1):1-10.

St. Gelais, A. T.; Chaves-Fonnegra, A.; Alison, L.; Moulding, A. L.; Kosmynin, V. N. \& Gilliam, D. S. 2016. Siderastrea siderea spawning and oocyteresorption at high latitude. Invertebrate Reproduction \& Development 60(3):212-222.

Szmant-Froelich, A.; Yevich, P. \& Pilson, M. E. Q. 1980. Gametogenesis and early development of the temperate coral Astrangia danae (Anthozoa: Scleractinia). Biological Bulletin 158:257-269.

Teixeira, C. D.; Leitão, R. L. L.; Ribeiro, F. V.; Moraes, F. C.; Neves, L. M.; Basto, A. C.; Pereira-Filho, G. H.; Kampel, M.; Salomon, P. S.; SÁ, J. A.; Falsarella, L. N.; Amario, M.; Abieri, M. L.; Pereira, R. C.; Amado-Filho, G. M. \& Moura, R. L. 2019. Sustained mass coral bleaching (2016-2017) in Brazilian turbidzone reefs: taxonomic, cross-shelf and habitat-related trends. Coral Reefs 38:801-813.

Traylor-Knowles, N.; Rose, N. H. \& Palumbi, S. R. 2017. The cell specificity of gene expression in the response to heat stress in corals. Journal of Experimental Biology 220:1837-1845.

Wall, C. B.; Ricci, C. A.; Foulds, G. E.; Mydlarz, L. D.; Gates, R. D. \& Putnam, H. M. 2018. The effects of environmental history and thermal stress on coral physiology and immunity. Marine Biology 165:56. http://doi.org/10.1007/s00227-018-3317-z.

Williams, G. J.; Work, T. M.; Aeby, G. S.; KnapP, I. S.; Davy, S. K. 2011. Gross and microscopic morphology of lesions in Cnidaria from Palmyra Atoll, Central Pacific. Journal of Invertebrate Pathology 106:165-173.

Work, T. M. \& AEBY, G. S. 2011. Pathology of tissue loss (white syndrome) in Acropora sp. Corals from the Central Pacific. Journal of Invertebrate Pathology 107:127-131.

Work, T. \& Meteyer, C. 2014. To understand coral disease, look at coral cells. EcoHealth 11:610-618.

Work, T. M.; Aeby, G. S. \& Hughen, K. A. 2016. Gross and Microscopic Lesions in Corals from Micronesia. Veterinary Pathology 53(1):153162.

ZAR, J. H. 2010. Biostatistical analysis. 5ed. New Jersey, Prentice Hall/ Pearson. 944p. 